\title{
Tolerance of seedlings traditional varieties of cowpea (Vigna unguiculata (L.) Walp.) to salt stress
}

\section{Tolerância de plântulas de variedades crioulas de feijão-caupi (Vigna unguiculata (L.) Walp.) ao estresse salino}

\author{
Saulo Samuel Carneiro Praxedes ${ }^{1}$; Francisco Vanies da Silva Sá2*; \\ Miguel Ferreira Neto ${ }^{3}$; Aline Torquato Loiola ${ }^{4}$; Layla Bruna Lopes Reges ${ }^{5}$; \\ Gleydson Dantas Jales ${ }^{6}$; Alberto Soares de Melo ${ }^{7}$
}

\section{Highlights:}

There is a genetic divergence among the cowpea varieties in terms of tolerance to salinity.

There are materials with a high tolerance to salinity among the traditional varieties of cowpea evaluated.

Salinity-tolerant varieties will increase species productivity in arid and semi-arid regions.

\begin{abstract}
Cowpea is an important source of protein, being the main subsistence crop in the northeast region of Brazil, where water restriction and salinity are limiting factors. Identification of saline stress tolerant varieties can aid crop expansion and improve crop yields. The objective was to study the tolerance of traditional varieties of cowpea to the salinity of irrigation water in the emergency and initial growth phase. The experiment was carried out in a greenhouse using a completely randomized design (DIC), in a 23 x 2 factorial scheme, composed of 23 cowpea varieties (Canapu Vermelho, Boquinha, Pingo de Ouro, Sempre Verde, Ceará, Baeta, Manteiga, Roxão, Costela de Vaca, Feijão Branco, Coruja, Rabo de Peba Branco, Sopinha, Canapu Branco, Lisão, Canapu Miúdo, Sempre Verde Ligeiro, Vagem Roxa, Ovo de Peru, Rabo de Peba Miúdo, Feijão Azul, Canário, and Paulistinha) and two levels of salinity of irrigation water $\left(\mathrm{S}_{1}=0.5\right.$ and $\mathrm{S}_{2}=5.5 \mathrm{dS} \mathrm{m} \mathrm{m}^{-1}$ ), with four repetitions of 50 seeds. The seedlings were evaluated for emergence, vigor, salinity tolerance index, and dissimilarity. Increased salinity of irrigation water reduced emergence, vigor and dry matter accumulation of cowpea varieties. The cowpea varieties 'Lisão', 'Costela de Vaca', 'Canário', 'Feijão Branco', 'Ceará', and 'Boquinha' are the most tolerant to salinity, while the varieties 'Sempre Verde' and 'Manteiga' are the most sensitive to salinity in the emergency and initial growth phase.
\end{abstract}

Key words: Growth. Emergency. Salinity of the water.

\footnotetext{
1 Discente do Curso de Doutorado do Programa de Pós-Graduação em Manejo de Solo e Água, Universidade Federal Rural do Semi-Árido, UFERSA, Mossoró, RN, Brasil. E-mail: saulosamuel@rn.gov.br

2 Pós-Doutorando, Programa de Pós-Graduação em Manejo de Solo e Água, UFERSA, Mossoró, RN, Brasil. E-mail: vanies_ agronomia@hotmail.com

3 Prof. Dr., UFERSA, Mossoró, RN, Brasil. E-mail: miguel@ufersa.edu.br

4 Discente do Curso de Mestrado do Programa de Pós-Graduação em Manejo de Solo e Água, UFERSA, Mossoró, RN, Brasil. E-mail: ninator4@gmail.com

5 Discente do Curso de Graduação em Engenharia Agrícola, UFERSA, Mossoró, RN, Brasil. E-mail: laylabruna69@gmail.com

6 Discente do Curso de Graduação em Agronomia, UFERSA, Mossoró, RN, Brasil. E-mail: gleydsondantas1991@gmail.com

7 Prof. Dr., Universidade Estadual da Paraíba, UEPB, Campina Grande, PB, Brasil. E-mail: alberto@uepb.edu.br

* Author for correspondence
}

Received: Aug. 08, 2019 - Approved: Mar. 13, 2020 


\section{Resumo}

O feijão-caupi é uma importante fonte de proteína, sendo a principal cultura de subsistência da região Nordeste do Brasil, onde a restrição de água e a salinidade são fatores limitantes. A identificação de variedades tolerantes ao estresse salino pode auxiliar na expansão da cultura, além de melhorar o rendimento dos cultivos. Objetivou-se estudar a tolerância de variedades crioulas de feijão-caupi à salinidade da água de irrigação na fase de emergência e crescimento inicial. O experimento foi realizado em casa de vegetação, usando o delineamento inteiramente casualizado (DIC), em esquema fatorial 23 x 2, composto de 23 variedades de feijão-caupi (Canapu Vermelho, Boquinha, Pingo de Ouro, Sempre Verde, Ceará, Baeta, Manteiga, Roxão, Costela de Vaca, Feijão Branco, Coruja, Rabo de Peba Branco, Sopinha, Canapu Branco, Lisão, Canapu Miúdo, Sempre Verde Ligeiro, Vagem Roxa, Ovo de Peru, Rabo de Peba Miúdo, Feijão Azul, Canário e Paulistinha), e dois níveis de salinidade da água de irrigação ( $\mathrm{S}_{1}$ $\left.=0,5 \mathrm{e} \mathrm{S}_{2}=5,5 \mathrm{dS} \mathrm{m}^{-1}\right)$, com quatro repetições de 50 sementes. As plântulas foram avaliadas quanto à emergência, o vigor, o índice de tolerância à salinidade e à dissimilaridade. $\mathrm{O}$ aumento da salinidade da água de irrigação reduziu a emergência, o vigor e acúmulo de massa seca das variedades de feijão-caupi. As variedades de feijão-caupi Lisão, Costela de Vaca, Canário, Feijão Branco, Ceará e Boquinha são as mais tolerantes à salinidade, enquanto que as variedades Sempre Verde e Manteiga são as mais sensíveis à salinidade na fase de emergência e crescimento inicial.

Palavras-chave: Crescimento. Emergência. Salinidade da água.

\section{Introduction}

Cowpea (Vigna unguiculata (L.) Walp.), also known in Portuguese as 'feijão-de-corda' or 'feijãomacassar', is one of the main subsistence crops in the north and northeast regions of Brazil, standing out as the main source of protein in the population diet (Melo et al., 2018). In the northeast region, it is mainly cultivated by family farmers, using a low technological level and family labor, with creole or traditional seeds for sowing (Chagas, Farias, Souza, Freitas, \& Costa, 2018).

An creole or traditional variety is understood to be one that has been managed in the same ecosystem for at least three family generations a period along which historical values are incorporated and has become part of local traditions (Machado, Santilli, \& Magalhães, 2008). This process does not represent a direct heredity through the family, as it may occur through the heredity of the community, within a collective process. It is important to highlight that the use of traditional seeds is a promising strategy for cultivation in the semi-arid region, since they have been selected by producers for being adapted and producing even under limiting conditions (Souza et al., 2019).
However, the climatic characteristics of the northeast region of Brazil have remarkable aspects, particularly the rains concentrated in short periods of the year, low relative humidity, and high temperatures (Melo et al., 2018). In addition, the Brazilian semi-arid region also has high contents of salts in part of the ground and surface water sources (Oliveira, 2015). In the Mossoró/Açu Agricultural Center region, in the state of Rio Grande do Norte, the greater demand for water for irrigation has forced the use of waters with high salinity (greater than $3.0 \mathrm{dS} \mathrm{m}^{-1}$ ) (Porto et al., 2006).

Abiotic factors, such as drought and salinity, are the main causes of significant damage to crop growth, development, and production (Aquino, Bezerra, Alcântara, Lima, \& Sousa, 2017). According to Coelho, Barros, Bezerra and Souza (2014), salinity in soil or water negatively influences the capacity of vegetables to absorb water, leading to metabolic alterations similar to those caused by water deficit.

In the evaluation of three cowpea cultivars, Patel, Kajalii, Pateli, Patel and Khristiii (2010) recorded that there were drastic reductions in biomass accumulation, as irrigation water salinity increased within the range from 0.75 to $10.0 \mathrm{dS} \mathrm{m}^{-1}$. 
According to Ayers and Westcot (1999), this crop tolerates irrigation with saline water with electrical conductivity of up to $3.3 \mathrm{dS} \mathrm{m}^{-1}$ and electrical conductivity of the soil saturation extract up to $4.9 \mathrm{dS} \mathrm{m}^{-1}$, being considered moderately tolerant to salinity. However, Sá et al. (2017a) found that irrigation water salinity above $1.5 \mathrm{dS} \mathrm{m}^{-1}$ reduces the emergence, growth, and dry mass accumulation of cowpea plants.

In studies conducted in the germination stage, Sá et al. $(2016,2017 b)$ found that the salinity tolerance of cowpea is variable among varieties, genotypes, and strains of this species. Thus, the objective was to study the tolerance of traditional varieties of cowpea to irrigation water salinity in the emergence and initial growth stage.

\section{Material and Methods}

The study was carried out in a greenhouse of the Department of Agronomic and Forestry Sciences of the Federal Rural University of the SemiArid Region (UFERSA), in Mossoró-RN, from March to April 2019. The municipality is located in the semi-arid region of northeastern Brazil, at local geographic coordinates of $5^{\circ} 11^{\prime} 31^{\prime \prime} \mathrm{S}$ and $37^{\circ} 20^{\prime} 40^{\prime \prime} \mathrm{W}$, at an altitude of $18 \mathrm{~m}$. Maximum and minimum temperatures of 40.4 and $22.8^{\circ} \mathrm{C}$ and maximum and minimum relative humidity values of
88.0 and $21.0 \%$, respectively, were recorded inside the greenhouse throughout the experimental period.

The experiment was conducted in a completely randomized design, in a $23 \times 2$ factorial scheme, with seeds of 23 traditional varieties of cowpea (V1 Canapu Vermelho, V2 Boquinha, V3 Pingo de Ouro, V4 Sempre Verde, V5 Ceará, V6 Baeta, V7 Manteiga, V8 Roxão, V9 Costela de Vaca, V10 Feijão Branco, V11 Coruja, V12 Rabo de Peba Branco, V13 Sopinha, V14 Canapu Branco, V15 Lisão, V16 Canapu Miúdo, V17 Sempre Verde Ligeiro, V18 Vagem Roxa, V19 Ovo de Peru, V20 Rabo de Peba Miúdo, V21 Feijão Azul, V22 Canário, and V23 Paulistinha), submitted to two levels of irrigation water salinity $\left(\mathrm{S}_{1}=0.5\right.$ and $\mathrm{S}_{2}$ $=5.5 \mathrm{dS} \mathrm{m}^{-1}$ ), with four replicates of 50 seeds each, totaling 184 experimental plots.

The two different levels of salinity were obtained using water from the local supply system $\left(\mathrm{ECw}=0.5 \mathrm{dS} \mathrm{m}^{-1}\right)$ and by the addition of $\mathrm{NaCl}$, $\mathrm{CaCl}_{2} \cdot 2\left(\mathrm{H}_{2} \mathrm{O}\right)$ and $\mathrm{MgCl}_{2} \cdot 6\left(\mathrm{H}_{2} \mathrm{O}\right)$ in the proportion of $7 \times 2 \times 1$, (Na:Ca:Mg), respectively, which is the proportion of ions found in the waters used for irrigation in Northeastern Brazil (Medeiros, Lisboa, Oliveira, Silva, \& Alves, 2003), mixing the salts as needed until reaching the desired level $(\mathrm{ECW}=5.5$ $\mathrm{dS} \mathrm{m}^{-1}$ ). The chemical composition of the water is shown in Table 1.

Table 1

Chemical characterization of the waters used in the experiment

\begin{tabular}{|c|c|c|c|c|c|c|c|c|c|c|}
\hline & \multicolumn{10}{|c|}{ Parameters } \\
\hline & $\mathrm{pH}$ & $\mathrm{EC}$ & $\mathrm{K}^{+}$ & $\mathrm{Na}^{+}$ & $\mathrm{Mg}^{2+}$ & $\mathrm{Ca}^{2+}$ & $\mathrm{Cl}^{-}$ & $\mathrm{CO}_{3}^{2-}$ & $\mathrm{HCO}_{3}^{-}$ & SAR \\
\hline & & $\mathrm{dS} \mathrm{m}^{-1}$ & & --------. & 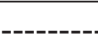 & $---m m$ & $-1-1$ & ------ & ------- & \\
\hline $\mathrm{S} 1$ & 7.37 & 0.50 & 0.31 & 2.79 & 1.20 & 0.83 & 1.90 & 0.60 & 2.70 & 1.96 \\
\hline $\mathrm{S} 2$ & 7.97 & 5.50 & 0.32 & 37.81 & 6.15 & 10.92 & 51.95 & 0.60 & 2.70 & 9.15 \\
\hline
\end{tabular}

pH - Hydrogen potential; EC - Electrical conductivity; $\mathrm{K}^{+}$- Potassium; $\mathrm{Na}^{+}$- Sodium; $\mathrm{Mg}^{2+}-\mathrm{Magnesium} ; \mathrm{Ca}^{2+}-\mathrm{Calcium}^{2} \mathrm{Cl}^{-}$Chlorine; $\mathrm{CO}_{3}^{2-}$ - Carbonate; $\mathrm{HCO}_{3}^{-}$- Bicarbonate; SAR - Sodium adsorption ratio.

The waters were prepared and stored in $150-\mathrm{L}$ plastic containers, one for each $\mathrm{EC}_{\mathrm{w}}$ level studied. The values were monitored with a portable electrical conductivity meter (Lutron, CD-4301), with conductivity adjusted to a temperature of $25^{\circ} \mathrm{C}$. 
The seeds used were acquired from collections owned by traditional seed guardians belonging to rural communities located in municipalities of the western region of Rio Grande do Norte State. The seeds came from the 2018 season and were stored in PET bottles, which were sealed to avoid any change in moisture level and stored in dry, well ventilated warehouses, without the use of preservatives. Sowing occurred on March 30, 2019, in trays with 200 cells, filled with coconut fiber substrate, using one seed per cell planted at $1.0 \mathrm{~cm}$ depth.

Irrigation management consisted of two daily irrigations, which were carried out using a floatingtype seedling irrigation system, through the direct contact of the trays with a $3.0-\mathrm{cm}$-thick water film so that the water reached the root growth medium by capillary rise. In order to form this water film, two reservoirs lined with waterproof tarpaulin were built with $1.0 \mathrm{~m}^{2}$ area and $5.0 \mathrm{~cm}$ depth each, with one for each level of irrigation water salinity (Oliveira et al., 2014).

From the $3^{\text {rd }}$ day after sowing, the number of emerged seedlings (cotyledons above soil level) was counted, without discarding them, in order to obtain a cumulative value until the $8^{\text {th }}$ day after sowing, following the guidelines of the Rules for Seed Analysis (Ministério da Agricultura, Pecuária e Abastecimento [MAPA], 2009). Thus, the number of emerging seedlings, referring to each count, was obtained by subtracting the reading of the previous day from the value of the current day. The number of emerging seedlings, referring to each reading, was used to calculate the emergence speed index (ESI), using the formula of Maguire (1962), which is the sum of the average daily emergence, according to Eq. 1.

$$
E S I=\frac{E 1}{T 1}+\frac{E 2}{T 2}+\cdots+\frac{E i}{T i}(\text { Equation } 1)
$$

Where: ESI is the emergence speed index; E1 up to Ei is the number of emergence occurred every day, and $\mathrm{T} 1 \mathrm{up}$ to $\mathrm{Ti}$ is the time (days).
On the $8^{\text {th }}$ day after sowing, with the end of the emergence test, the normal seedlings of the plot were collected, separated into shoots (leaves + stem) and roots, and dried in a forced air circulation oven at $65^{\circ} \mathrm{C}$, until constant weight. Then the material was weighed on an analytical scale with accuracy of $0.001 \mathrm{~g}$. These data were used to calculate shoot dry mass (SDM), root dry mass (RDM), and total dry mass (TDM) (SDM + RDM), with data expressed in $\mathrm{mg}$.

These data of total dry mass were used to calculate the percentages partitioned among the vegetative organs and the salinity tolerance index. For this, data of saline treatment $\left(\mathrm{S}_{2}\right)$ were compared to those of the control $\left(\mathrm{EC}_{\mathrm{w}}=0.5 \mathrm{dS} \mathrm{m}^{-1}\right)$ (Fageria, Soares, $\&$ Gheyi, 2010), based on the classification into four levels depending on the yield loss: $\mathrm{T}$ (tolerant; 0-20\%), MT (moderately tolerant; 21-40\%), MS (moderately sensitive; 41-60\%), and S (sensitive; $>60 \%$ ), as shown in Eq. 2 .

$\mathrm{STI}(\%)=\frac{\mathrm{TDM} \text { production in the saline treatment }}{\mathrm{TDM} \text { production in the control treatment }} \times 100$

(Equation 2)

These indices were calculated using the total dry mass of each variety as the main parameter to determine the tolerance of the materials to salt stress. The collected data were submitted to analysis of variance by $F$ test. In case of significance, the Scott-Knott grouping test was applied to the variety factor and Student's t-test was applied to the salinity factor, both at 0.05 significance level, using the software SISVAR ${ }^{\circledR}$ for statistical analyses (Ferreira, 2014). The data of emergence percentage and total dry mass were standardized to zero mean $(=0)$ and unit variance $\left(S^{2}=1\right)$. Subsequently, cluster analysis was performed by the hierarchical method, Ward's minimum variance, using the Euclidean distance as a dissimilarity measure (Hair, Black, Babin, Anderson, \& Tatham, 2009). The free software program PAST 3 was used for the univariate and multivariate statistical analyses. 


\section{Results and Discussion}

There was significant interaction between varieties and salinity levels for emergence percentage (EP), emergence speed index (ESI), shoot dry mass (SDM), total dry mass (TDM), and salinity tolerance index (STI) at $1 \%$ probability level $(P<0.01)$ and for root dry mass $(\mathrm{RDM})$ at $5 \%$ probability level (Table 2 ).

Table 2

Summary of the F test for emergence percentage (EP), emergence speed index (ESI), shoot dry mass (SDM), root dry mass (RDM), total dry mass (TDM) and salinity tolerance index (STI) of traditional varieties of cowpea subjected to levels of irrigation water salinity

\begin{tabular}{cccccccc}
\hline \multirow{2}{*}{$\begin{array}{c}\text { Sources of } \\
\text { variation }\end{array}$} & $\begin{array}{c}\text { Degrees of } \\
\text { freedom }\end{array}$ & \multicolumn{7}{c}{$\operatorname{Pr}>\mathrm{Fc}$} \\
\cline { 3 - 7 } & 3 & $0.426^{\mathrm{NS}}$ & $0.644^{\mathrm{NS}}$ & $0.352^{\mathrm{NS}}$ & $0.351^{\mathrm{NS}}$ & $0.130^{\mathrm{NS}}$ & $0.702^{\mathrm{NS}}$ \\
\hline Block & 3 & $0.302^{\mathrm{NS}}$ & $0.000^{* *}$ & $0.000^{* *}$ & $0.000^{* *}$ & $0.000^{* *}$ & $0.000^{* *}$ \\
Salinity (S) & 1 & $0.000^{* *}$ & $0.000^{* *}$ & $0.000^{* *}$ & $0.000^{* *}$ & $0.000^{* *}$ & $0.000^{* *}$ \\
Variety (V) & 22 & $0.000^{* *}$ & $0.000^{* *}$ & $0.000^{* *}$ & $0.047^{*}$ & $0.000^{* *}$ & $0.000^{* *}$ \\
S x G & 22 & -- & -- & -- & -- & -- & -- \\
Error & 135 & -- & 14.98 & 17.76 & 15.03 & 9.11 \\
\hline \multicolumn{2}{l}{ Coefficient of variation (\%) } & 7.26 & 9.24 & &
\end{tabular}

** significant at $1 \%(\mathrm{p}<0.01) ;{ }^{*}$ significant at $5 \%(\mathrm{p}<0.05) ;{ }^{\text {NS }}$ not significant; ${ }^{1}$ data transformed to square root.

The emergence percentage of the cowpea variety 7 Manteiga was the only one reduced by salinity, decreasing by $27 \%$ between the levels of 0.5 and 5.5 $\mathrm{dS} \mathrm{m}{ }^{-1}$, which indicates a lower level of tolerance of this variety in the germination/emergence stage (Table 3). At the level of highest salinity, varieties 2 Boquinha, 5 Ceará, 6 Baeta, 8 Roxão, 9 Costela de Vaca, 14 Canapu Branco, 16 Canapu Miúdo, 19 Ovo de Peru, 20 Rabo de Peba Miúdo, 21 Feijão Azul, 22 Canário, and 23 Paulistinha showed the best values of emergence (Table 3 ).

The emergence speed indices (ESI) of varieties 1 Canapu Vermelho, 4 Sempre Verde, 7 Manteiga, 8 Roxão, 9 Costela de Vaca, 11 Coruja, 12 Rabo de Peba Branco, 17 Sempre Verde Ligeiro, 18 Vagem Roxa, and 20 Rabo de Peba Miúdo were also reduced with an increase in irrigation water salinity. These results demonstrate that salt stress slows the emergence of seedlings of the cowpea varieties more prone to sensitivity to salt stress, but it was not enough to reduce EP, except for the variety 7 Manteiga (Table 3). However, under high salinity, the varieties 5 Ceará, 6 Baeta, 13 Sopinha, and 23
Paulistinha showed the best ESI (Table 3).

Similar results have been reported by Santos et al. (2009), Almeida, Fernandes, Bertini, Pinheiro and Teófilo (2012), and Sá et al. (2017b) when evaluating salt stress ( 0.0 to $\left.16.66 \mathrm{dS} \mathrm{m}^{-1}\right)$ on the germination of cowpea seeds. These researchers observed that the osmotic effect compromises the germination and vigor of seedlings because it reduces the speed and uniformity of germination, initial size, and adequate establishment because of the damage to the capacity of degradation of the reserves resulting from the lower hydration of the tissues.

In a general analysis of emergence percentage and speed index of the varieties under conditions of high salinity, traditional varieties 5 Ceará, 6 Baeta, and 23 Paulistinha showed the best performance in the emergence stage (Table 3). This occurred because of the capacity of some genotypes to perform osmotic homeostasis, which favors the hydration of tissues at osmotic potentials that are unfavorable to the species (Syvertsen \& GarciaSanchez, 2014; Sá et al., 2017b). 
Table 3

Emergence percentage (EP) and emergence speed index (ESI) of traditional varieties of cowpea subjected to irrigation water salinity

\begin{tabular}{|c|c|c|c|c|c|c|c|c|}
\hline \multirow{3}{*}{$\begin{array}{c}\text { Varieties } \\
1 \text { - Canapu Vermelho }\end{array}$} & \multicolumn{4}{|c|}{ EP (\%) } & \multicolumn{4}{|c|}{ ESI } \\
\hline & \multicolumn{2}{|c|}{$0.5 \mathrm{dS} \mathrm{m}^{-1}$} & \multicolumn{2}{|c|}{$5.5 \mathrm{dS} \mathrm{m}^{-1}$} & \multicolumn{2}{|c|}{$0.5 \mathrm{dS} \mathrm{m}^{-1}$} & \multicolumn{2}{|c|}{$5.5 \mathrm{dS} \mathrm{m}^{-1}$} \\
\hline & 87 & $\mathrm{Ab}$ & 88 & $\mathrm{Ab}$ & 21.5 & $\mathrm{Ab}$ & 17.8 & $\mathrm{Bc}$ \\
\hline 2 - Boquinha & 94 & $\mathrm{Aa}$ & 97 & $\mathrm{Aa}$ & 25.7 & Aa & 24.4 & $\mathrm{Ab}$ \\
\hline 3 - Pingo de Ouro & 84 & $\mathrm{Ab}$ & 76 & Ac & 19.3 & Ac & 17.5 & Ac \\
\hline 4 - Sempre Verde & 89 & $\mathrm{Ab}$ & 83 & $\mathrm{Ab}$ & 24.7 & $\mathrm{Aa}$ & 17.6 & $\mathrm{Bc}$ \\
\hline 5 - Ceará & 90 & $\mathrm{Aa}$ & 99 & $\mathrm{Aa}$ & 25.7 & $\mathrm{Aa}$ & 28.6 & $\mathrm{Aa}$ \\
\hline 6 - Baeta & 92 & $\mathrm{Aa}$ & 94 & $\mathrm{Aa}$ & 27.0 & $\mathrm{Aa}$ & 26.9 & $\mathrm{Aa}$ \\
\hline 7 - Manteiga & 82 & $\mathrm{Ab}$ & 60 & $\mathrm{Bd}$ & 17.8 & Ac & 11.5 & $\mathrm{Bd}$ \\
\hline 8 - Roxão & 99 & $\mathrm{Aa}$ & 96 & $\mathrm{Aa}$ & 28.7 & $\mathrm{Aa}$ & 21.9 & $\mathrm{Bb}$ \\
\hline 9 - Costela de Vaca & 97 & $\mathrm{Aa}$ & 92 & $\mathrm{Aa}$ & 23.4 & $\mathrm{Ab}$ & 19.1 & $\mathrm{Bc}$ \\
\hline 10 - Feijão Branco & 87 & $\mathrm{Ab}$ & 84 & $\mathrm{Ab}$ & 24.6 & $\mathrm{Aa}$ & 23.1 & $\mathrm{Ab}$ \\
\hline 11 - Coruja & 93 & $\mathrm{Aa}$ & 90 & $\mathrm{Ab}$ & 25.8 & $\mathrm{Aa}$ & 20.8 & $\mathrm{Bc}$ \\
\hline 12 - Rabo de Peba Branco & 77 & $\mathrm{Ab}$ & 69 & $\mathrm{Ac}$ & 21.9 & $\mathrm{Ab}$ & 18.0 & $\mathrm{Bc}$ \\
\hline 13 - Sopinha & 93 & $\mathrm{Aa}$ & 88 & $\mathrm{Ab}$ & 27.6 & $\mathrm{Aa}$ & 25.9 & $\mathrm{Aa}$ \\
\hline 14 - Canapu branco & 100 & $\mathrm{Aa}$ & 98 & $\mathrm{Aa}$ & 25.2 & $\mathrm{Aa}$ & 23.1 & $\mathrm{Ab}$ \\
\hline 15 - Lisão & 92 & $\mathrm{Aa}$ & 85 & $\mathrm{Ab}$ & 26.7 & $\mathrm{Aa}$ & 24.3 & $\mathrm{Ab}$ \\
\hline 16 - Canapu miúdo & 87 & $\mathrm{Bb}$ & 97 & $\mathrm{Aa}$ & 22.6 & $\mathrm{Ab}$ & 24.1 & $\mathrm{Ab}$ \\
\hline 17 - Sempre Verde Ligeiro & 89 & $\mathrm{Ab}$ & 90 & $\mathrm{Ab}$ & 25.0 & $\mathrm{Aa}$ & 19.9 & $\mathrm{Bc}$ \\
\hline 18 - Vagem roxa & 95 & $\mathrm{Aa}$ & 86 & $\mathrm{Ab}$ & 27.4 & $\mathrm{Aa}$ & 22.2 & $\mathrm{Bb}$ \\
\hline 19 - Ovo de Peru & 79 & $\mathrm{Ab}$ & 92 & $\mathrm{Aa}$ & 18.7 & Ac & 20.9 & Ac \\
\hline 20 - Rabo de Peba Miúdo & 95 & $\mathrm{Aa}$ & 94 & $\mathrm{Aa}$ & 25.1 & $\mathrm{Aa}$ & 19.2 & $\mathrm{Bc}$ \\
\hline 21 - Feijão Azul & 88 & $\mathrm{Ab}$ & 97 & $\mathrm{Aa}$ & 22.4 & $\mathrm{Ab}$ & 22.4 & $\mathrm{Ab}$ \\
\hline 22 - Canário & 95 & $\mathrm{Aa}$ & 99 & $\mathrm{Aa}$ & 22.6 & $\mathrm{Ab}$ & 22.7 & $\mathrm{Ab}$ \\
\hline 23 - Paulistinha & 93 & $\mathrm{Aa}$ & 99 & $\mathrm{Aa}$ & 26.6 & $\mathrm{Aa}$ & 26.0 & $\mathrm{Aa}$ \\
\hline
\end{tabular}

Equal letters, uppercase in rows and lowercase in columns, do not differ by Student's t-test and Scott-Knott test at $5 \%$ probability level, respectively.

In a study about salt stress on cowpea germination, Sá et al. (2016) observed that there was no difference between levels of irrigation water salinity $\left(0.0\right.$ to $\left.8.0 \mathrm{dS} \mathrm{m}^{-1}\right)$ in the germination of the cultivars Paulistinha and Canapu Branco, while other varieties, such as Pingo de Ouro and Costela de Vaca, were affected in the germination stage. This confirms the response of cowpea to salinity, which is variable within the same species from the initial development stage.
The accumulation of dry mass in the shoots of varieties 1 Canapu Vermelho; 2 Boquinha; 3 Pingo de Ouro; 4 Sempre Verde; 6 Baeta; 7 Manteiga; 8 Roxão; 9 Costela de Vaca; 11 Coruja; 12 Rabo de Peba Branco; 14 Canapu Branco; 16 Canapu Miúdo; 17 Sempre Verde Ligeiro; 18 Vagem Roxa; 19 Ovo de Peru; 20 Rabo de Peba Miúdo; 21 Feijão Azul, and 23 Paulistinha were reduced as water salinity increased from 0.5 to $5.5 \mathrm{dS} \mathrm{m}^{-1}$, with reductions up to $70.3 \%$ that observed in variety 4 Sempre Verde (Table 4). 
Table 4

Shoot dry mass (SDM) and root dry mass (RDM) of traditional varieties of cowpea subjected to irrigation water salinity

\begin{tabular}{|c|c|c|c|c|c|c|c|c|}
\hline \multirow{3}{*}{$\begin{array}{c}\text { Varieties } \\
1-\text { Canapu Vermelho }\end{array}$} & \multicolumn{4}{|c|}{ SDM (mg) } & \multicolumn{4}{|c|}{ RDM (mg) } \\
\hline & \multicolumn{2}{|c|}{$0.5 \mathrm{dS} \mathrm{m}^{-1}$} & \multicolumn{2}{|c|}{$5.5 \mathrm{dS} \mathrm{m}^{-1}$} & \multicolumn{2}{|c|}{$0.5 \mathrm{dS} \mathrm{m}^{-1}$} & \multicolumn{2}{|c|}{$5.5 \mathrm{dS} \mathrm{m}^{-1}$} \\
\hline & 171.4 & $\mathrm{Aa}$ & 87.2 & $\mathrm{Bc}$ & 30.5 & $\mathrm{Ab}$ & 16.5 & $\mathrm{Bb}$ \\
\hline 2 - Boquinha & 128.8 & $\mathrm{Ab}$ & 105.2 & $\mathrm{Bb}$ & 16.1 & Ac & 14.3 & $\mathrm{Ab}$ \\
\hline 3 - Pingo de Ouro & 98.1 & Ac & 74.1 & $\mathrm{Bc}$ & 34.4 & $\mathrm{Ab}$ & 10.2 & $\mathrm{Bb}$ \\
\hline 4 - Sempre Verde & 154.8 & $\mathrm{Aa}$ & 45.9 & $\mathrm{Bd}$ & 29.7 & $\mathrm{Ab}$ & 12.0 & $\mathrm{Bb}$ \\
\hline 5 - Ceará & 140.8 & $\mathrm{Aa}$ & 121.3 & $\mathrm{Aa}$ & 31.6 & $\mathrm{Ab}$ & 25.6 & $\mathrm{Aa}$ \\
\hline 6 - Baeta & 147.6 & $\mathrm{Aa}$ & 82.2 & $\mathrm{Bc}$ & 24.9 & Ac & 16.9 & $\mathrm{Ab}$ \\
\hline 7 - Manteiga & 142.6 & $\mathrm{Aa}$ & 66.4 & $\mathrm{Bc}$ & 27.4 & Ac & 14.2 & $\mathrm{Bb}$ \\
\hline 8 - Roxão & 112.4 & $\mathrm{Ab}$ & 85.2 & $\mathrm{Bc}$ & 14.7 & Ac & 8.1 & $\mathrm{Ab}$ \\
\hline 9 - Costela de Vaca & 153.2 & $\mathrm{Aa}$ & 122.5 & $\mathrm{Ba}$ & 30.1 & $\mathrm{Ab}$ & 32.7 & $\mathrm{Aa}$ \\
\hline 10 - Feijão Branco & 149.9 & $\mathrm{Aa}$ & 134.9 & $\mathrm{Aa}$ & 30.0 & $\mathrm{Ab}$ & 24.5 & $\mathrm{Aa}$ \\
\hline 11 - Coruja & 145.7 & $\mathrm{Aa}$ & 79.5 & $\mathrm{Bc}$ & 24.8 & Ac & 16.9 & $\mathrm{Ab}$ \\
\hline 12 - Rabo de Peba Branco & 151.0 & $\mathrm{Aa}$ & 121.6 & $\mathrm{Ba}$ & 40.8 & $\mathrm{Aa}$ & 31.3 & $\mathrm{Aa}$ \\
\hline 13 - Sopinha & 73.6 & Ad & 52.9 & Ad & 22.7 & Ac & 18.1 & $\mathrm{Ab}$ \\
\hline 14 - Canapu branco & 123.1 & $\mathrm{Ab}$ & 69.7 & $\mathrm{Bc}$ & 23.1 & Ac & 25.8 & $\mathrm{Aa}$ \\
\hline 15 - Lisão & 102.1 & Ac & 105.3 & $\mathrm{Ab}$ & 33.0 & $\mathrm{Ab}$ & 25.9 & $\mathrm{Aa}$ \\
\hline 16 - Canapu miúdo & 107.8 & $\mathrm{Ab}$ & 69.2 & $\mathrm{Bc}$ & 19.6 & Ac & 17.5 & $\mathrm{Ab}$ \\
\hline 17 - Sempre Verde Ligeiro & 162.2 & $\mathrm{Aa}$ & 92.5 & $\mathrm{Bb}$ & 47.3 & $\mathrm{Aa}$ & 27.1 & $\mathrm{Ba}$ \\
\hline 18 - Vagem roxa & 154.5 & $\mathrm{Aa}$ & 76.0 & $\mathrm{Bc}$ & 25.5 & Ac & 12.0 & $\mathrm{Bb}$ \\
\hline 19 - Ovo de Peru & 151.8 & $\mathrm{Aa}$ & 99.5 & $\mathrm{Bb}$ & 27.1 & Ac & 18.3 & $\mathrm{Ab}$ \\
\hline 20 - Rabo de Peba Miúdo & 133.6 & $\mathrm{Aa}$ & 51.3 & $\mathrm{Bd}$ & 21.7 & Ac & 18.5 & $\mathrm{Ab}$ \\
\hline 21 - Feijão Azul & 125.0 & $\mathrm{Ab}$ & 60.7 & $\mathrm{Bd}$ & 19.7 & Ac & 16.7 & $\mathrm{Ab}$ \\
\hline 22 - Canário & 121.0 & $\mathrm{Ab}$ & 99.6 & $\mathrm{Ab}$ & 31.8 & $\mathrm{Ab}$ & 34.3 & $\mathrm{Aa}$ \\
\hline 23 - Paulistinha & 115.3 & $\mathrm{Ab}$ & 67.2 & $\mathrm{Bc}$ & 16.9 & Ac & 12.0 & $\mathrm{Ab}$ \\
\hline
\end{tabular}

Equal letters, uppercase in rows and lowercase in columns, do not differ by Student's t-test and Scott-Knott test at 5\% probability level, respectively.

The reduction in seed vigor caused by salt stress slows the establishment of plants in the field. This depletion is caused by reduction in the mobilization of reserves and induces disturbances in cell membranes, causing an increase in the osmotic pressure of the soil solution, consequently reducing water availability to the seeds (Barreto, Freitas, Oliveira, Araújo, \& Costa, 2010; Almeida et al. 2012; Coelho et al., 2014).

A similar result was found by Sá et al. (2017a), who observed a reduction in shoot dry mass accumulation of cowpea varieties, including Paulistinha, and by
Gomes, Almeida and Takahashi (2015), who verified the negative influence of water and salt stresses on the shoot dry mass accumulation of green bean.

However, in varieties 5 Ceará; 10 Feijão Branco; 13 Sopinha; 15 Lisão and 22 Canário, there was no significant reduction in shoot dry mass accumulation with the increase in the level of water salinity. This behavior suggests higher tolerance of the shoots of these varieties to salinity. At the level of highest salinity, the varieties 5 Ceará, 9 Costela de Vaca, 10 Feijão Branco, and 12 Rabo de Peba Branco had the highest values of shoot dry mass (Table 4). 
Table 3 shows that the varieties 1 Canapu Vermelho, 3 Pingo de Ouro, 4 Sempre Verde, 7 Manteiga, 17 Sempre Verde Ligeiro, and 18 Vagem Roxa showed reduction in shoot dry mass accumulation as water salinity increased, with reductions of up to $59.6 \%$ that in variety 4 Sempre Verde. Reductions in root dry mass in the presence of salts in the soil solution negatively affect nutrient absorption and, consequently, the accumulation of shoot dry mass, which has also been observed in other studies (Coelho, Agostini, Guaberto, Machado, \& Custódio, 2010; Gomes et al., 2015; Sá et al., 2017b).

In contrast, in some materials, the root dry mass accumulation was not influenced by the increase of salinity, as observed in varieties 2 Boquinha, 5 Ceará, 6 Baeta, 8 Roxão, 9 Costela de Vaca, 10 Feijão Branco, 11 Coruja, 12 Rabo de Peba Branco, 13 Sopinha, 14 Canapu Branco, 15 Lisão, 16 Canapu Miúdo, 19 Ovo de Peru, 20 Rabo de Peba Miúdo, 21 Feijão Azul, 22 Canário, and 23 Paulistinha.

Varieties 5 Ceará, 9 Costela de Vaca, 10 Feijão Branco, 12 Rabo de Peba Branco, 14 Canapu Branco, 15 Lisão, 17 Sempre Verde Ligeiro, and 22 Canário showed the highest accumulation of root dry mass at the highest level of water salinity compared to the other varieties studied (Table 4). Regarding seedlings subjected to salt stress, vigor is more affected than germination and/or emergence, causing greater reduction of biomass, which can be attributed to the decrease in cell division and expansion, leading to a reduction in seedling growth (Santos et al., 2009; Almeida et al., 2012; Lopes, Nascimento, Barbosa, \& Costa, 2014; Bernardes, Mengarda, Lopes, Nogueira, \& Rodrigues, 2015).

The total dry mass of varieties 1 Canapu Vermelho, 3 Pingo de Ouro, 4 Sempre Verde, 6 Baeta, 7 Manteiga, 8 Roxão, 9 Costela de Vaca, 11 Coruja, 12 Rabo de Peba Branco, 14 Canapu Branco, 16 Canapu Miúdo, 17 Sempre Verde Ligeiro, 18 Vagem Roxa, 19 Ovo de Peru, 20 Rabo de Peba Miúdo, 21 Feijão Azul, and 23 Paulistinha was significantly reduced $(P<0.05)$ with an increase in irrigation water salinity (Table 5). This fact indicates that salt stress affected the accumulation of carbohydrates in cowpea seedlings. This is possibly due to the reduction of reserve polysaccharides and the degradation of hydrolytic enzyme activity (cotyledons) (Sá et al., 2017b). Other reductions in dry mass accumulation in cowpea seedlings under salt stress have also been found by Santos et al. (2009) and Almeida et al. (2012).

Varieties 2 Boquinha, 5 Ceará, 10 Feijão Branco, 13 Sopinha, 15 Lisão, and 22 Canário were not influenced $(P<0.05)$ by an increase in water salinity level. This behavior suggests higher tolerance and absence of influence of the salts on the growth and development of these varieties. At the highest level of salinity, varieties 5 Ceará, 9 Costela de Vaca, 10 Feijão Branco, and 12 Rabo de Peba Branco had the highest values of total dry mass (Table 5).

In relation to the salinity tolerance index, only variety 15 Lisão was not significantly influenced $(P>0.05)$ by the increase in the level of water salinity. In addition, varieties 2 Boquinha, 5 Ceará, 9 Costela de Vaca, 10 Feijão Branco, and 22 Canário showed the best tolerance indices at the highest level of salinity.

In this study, four groups were formed as a function of the index of tolerance to irrigation water salinity. Varieties 2 Boquinha, 5 Ceará, 9 Costela de Vaca, 10 Feijão Branco, 15 Lisão, and 22 Canário were classified as tolerant ( $\mathrm{STI} \geq 80 \%$ ), and varieties 3 Pingo de Ouro, 8 Roxão, 12 Rabo de Peba Branco, 13 Sopinha, 14 Canapu Branco, 16 Canapu Miúdo, and 19 Ovo de Peru were classified as moderately tolerant $(60 \% \leq \mathrm{STI}<80 \%)$. Varieties 1 Canapu Vermelho, 6 Baeta, 7 Manteiga, 11 Coruja, 17 Sempre Verde Ligeiro, 18 Vagem Roxa, 20 Rabo de Peba Miúdo, 21 Feijão Azul, and 23 Paulistinha were classified as moderately sensitive $(40 \% \leq \mathrm{STI}<60 \%)$, while variety 4 Sempre Verde was the only one classified as sensitive (STI $<40 \%)$ (Fageria et al., 2010). 
Table 5

Total dry mass (TDM) and salinity tolerance index (STI) of traditional varieties of cowpea subjected to irrigation water salinity

\begin{tabular}{|c|c|c|c|c|c|c|c|c|}
\hline \multirow{3}{*}{$\begin{array}{c}\text { Varieties } \\
1 \text { - Canapu Vermelho }\end{array}$} & \multicolumn{4}{|c|}{ TDM (mg) } & \multicolumn{4}{|c|}{ STI (\%) } \\
\hline & \multicolumn{2}{|c|}{$0.5 \mathrm{dS} \mathrm{m}^{-1}$} & \multicolumn{2}{|c|}{$5.5 \mathrm{dS} \mathrm{m}^{-1}$} & \multicolumn{2}{|c|}{$0.5 \mathrm{dS} \mathrm{m}^{-1}$} & \multicolumn{2}{|c|}{$5.5 \mathrm{dS} \mathrm{m}^{-1}$} \\
\hline & 201.9 & $\mathrm{Aa}$ & 103.7 & $\mathrm{Bc}$ & 100 & $\mathrm{Aa}$ & 51.3 & $\mathrm{Be}$ \\
\hline 2 - Boquinha & 144.9 & $\mathrm{Ab}$ & 119.5 & $\mathrm{Ab}$ & 100 & $\mathrm{Aa}$ & 82.5 & $\mathrm{Ba}$ \\
\hline 3 - Pingo de Ouro & 132.5 & $\mathrm{Ab}$ & 84.3 & $\mathrm{Bc}$ & 100 & $\mathrm{Aa}$ & 63.6 & $\mathrm{Bc}$ \\
\hline 4 - Sempre Verde & 184.5 & $\mathrm{Aa}$ & 57.9 & $\mathrm{Bc}$ & 100 & $\mathrm{Aa}$ & 31.4 & $\mathrm{Bf}$ \\
\hline 5 - Ceará & 172.5 & $\mathrm{Aa}$ & 146.9 & $\mathrm{Aa}$ & 100 & $\mathrm{Aa}$ & 85.2 & $\mathrm{Ba}$ \\
\hline 6 - Baeta & 172.5 & $\mathrm{Aa}$ & 99.1 & $\mathrm{Bc}$ & 100 & $\mathrm{Aa}$ & 57.5 & $\mathrm{Bd}$ \\
\hline 7 - Manteiga & 170.0 & $\mathrm{Aa}$ & 80.6 & $\mathrm{Bc}$ & 100 & $\mathrm{Aa}$ & 47.4 & $\mathrm{Be}$ \\
\hline 8 - Roxão & 127.2 & $\mathrm{Ab}$ & 93.3 & $\mathrm{Bc}$ & 100 & $\mathrm{Aa}$ & 73.4 & $\mathrm{Bb}$ \\
\hline 9 - Costela de Vaca & 183.3 & $\mathrm{Aa}$ & 155.1 & $\mathrm{Ba}$ & 100 & $\mathrm{Aa}$ & 82.7 & $\mathrm{Ba}$ \\
\hline 10 - Feijão Branco & 180.0 & $\mathrm{Aa}$ & 159.4 & $\mathrm{Aa}$ & 100 & $\mathrm{Aa}$ & 88.4 & $\mathrm{Ba}$ \\
\hline 11 - Coruja & 170.5 & $\mathrm{Aa}$ & 96.4 & $\mathrm{Bc}$ & 100 & $\mathrm{Aa}$ & 56.5 & $\mathrm{Bd}$ \\
\hline 12 - Rabo de Peba Branco & 191.8 & $\mathrm{Aa}$ & 152.9 & $\mathrm{Ba}$ & 100 & $\mathrm{Aa}$ & 79.7 & $\mathrm{Bb}$ \\
\hline 13 - Sopinha & 96.2 & Ac & 71.0 & $\mathrm{Ac}$ & 100 & $\mathrm{Aa}$ & 73.7 & $\mathrm{Bb}$ \\
\hline 14 - Canapu branco & 146.1 & $\mathrm{Ab}$ & 95.5 & $\mathrm{Bc}$ & 100 & $\mathrm{Aa}$ & 65.3 & $\mathrm{Bc}$ \\
\hline 15 - Lisão & 135.1 & $\mathrm{Ab}$ & 131.2 & $\mathrm{Ab}$ & 100 & $\mathrm{Aa}$ & 92.2 & $\mathrm{Aa}$ \\
\hline 16 - Canapu miúdo & 127.3 & $\mathrm{Ab}$ & 86.7 & $\mathrm{Bc}$ & 100 & $\mathrm{Aa}$ & 68.1 & $\mathrm{Bc}$ \\
\hline 17 - Sempre Verde Ligeiro & 209.5 & $\mathrm{Aa}$ & 119.6 & $\mathrm{Bb}$ & 100 & $\mathrm{Aa}$ & 57.1 & $\mathrm{Bd}$ \\
\hline 18 - Vagem roxa & 180.0 & $\mathrm{Aa}$ & 88.0 & $\mathrm{Bc}$ & 100 & $\mathrm{Aa}$ & 48.9 & $\mathrm{Be}$ \\
\hline 19 - Ovo de Peru & 178.9 & $\mathrm{Aa}$ & 117.7 & $\mathrm{Bb}$ & 100 & $\mathrm{Aa}$ & 65.8 & $\mathrm{Bc}$ \\
\hline 20 - Rabo de Peba Miúdo & 155.2 & $\mathrm{Ab}$ & 69.8 & $\mathrm{Bc}$ & 100 & $\mathrm{Aa}$ & 45.0 & $\mathrm{Be}$ \\
\hline 21 - Feijão Azul & 144.7 & $\mathrm{Ab}$ & 77.5 & $\mathrm{Bc}$ & 100 & $\mathrm{Aa}$ & 53.5 & $\mathrm{Bd}$ \\
\hline 22 - Canário & 152.8 & $\mathrm{Ab}$ & 133.9 & $\mathrm{Ab}$ & 100 & $\mathrm{Aa}$ & 87.6 & $\mathrm{Ba}$ \\
\hline 23 - Paulistinha & 132.1 & $\mathrm{Ab}$ & 79.2 & $\mathrm{Bc}$ & 100 & $\mathrm{Aa}$ & 59.9 & $\mathrm{Bd}$ \\
\hline
\end{tabular}

Equal letters, uppercase in rows and lowercase in columns, do not differ by Student's t-test and Scott-Knott test at 5\% probability level, respectively.

In the cluster analysis, the Euclidean distance was used as a measure of dissimilarity, with a cutpoint at a distance of 0.13 for the formation of six groups of combinations between salinity levels (S) and cowpea varieties (V). The first group (I) was characterized by the 23 varieties under the condition of low salinity $\left(0.5 \mathrm{dS} \mathrm{m}^{-1}\right)$ that is, the absence of salt stress. In group two (II), conglomerates can be characterized by the varieties with better emergence percentage and higher dry mass accumulation under the condition of high salinity, which are the most tolerant, in this order: V12 Rabo de Peba Branco;
V15 Lisão; V9 Costela de Vaca; V22 Canário; V10 Feijão Branco; V5 Ceará, and V2 Boquinha (Figure $1)$.

The third group (III) contains varieties V19 Ovo de Peru, V16 Canapu Miúdo, V14 Canapu Branco, V13 Sopinha, V8 Roxão, V3 Pingo de Ouro, while the fourth group (IV) comprised the varieties V18 Vagem Roxa, V20 Rabo de Peba Miúdo, V23 Paulistinha, V11 Coruja, V17 Sempre Verde Ligeiro, V6 Baeta, V21 Feijão Azul, and V1 Canapu Vermelho (Figure 1). By correlating these data with 
those of STI, it can be inferred that group III includes varieties with moderate tolerance to salinity, and group IV contains those with moderate sensitivity to salinity (Table 5). Groups V and IV include varieties
V7 Manteiga and V4 Sempre Verde, respectively, which had the worst performances in emergence and biomass accumulation, standing out as sensitive to salinity (Figure 1).

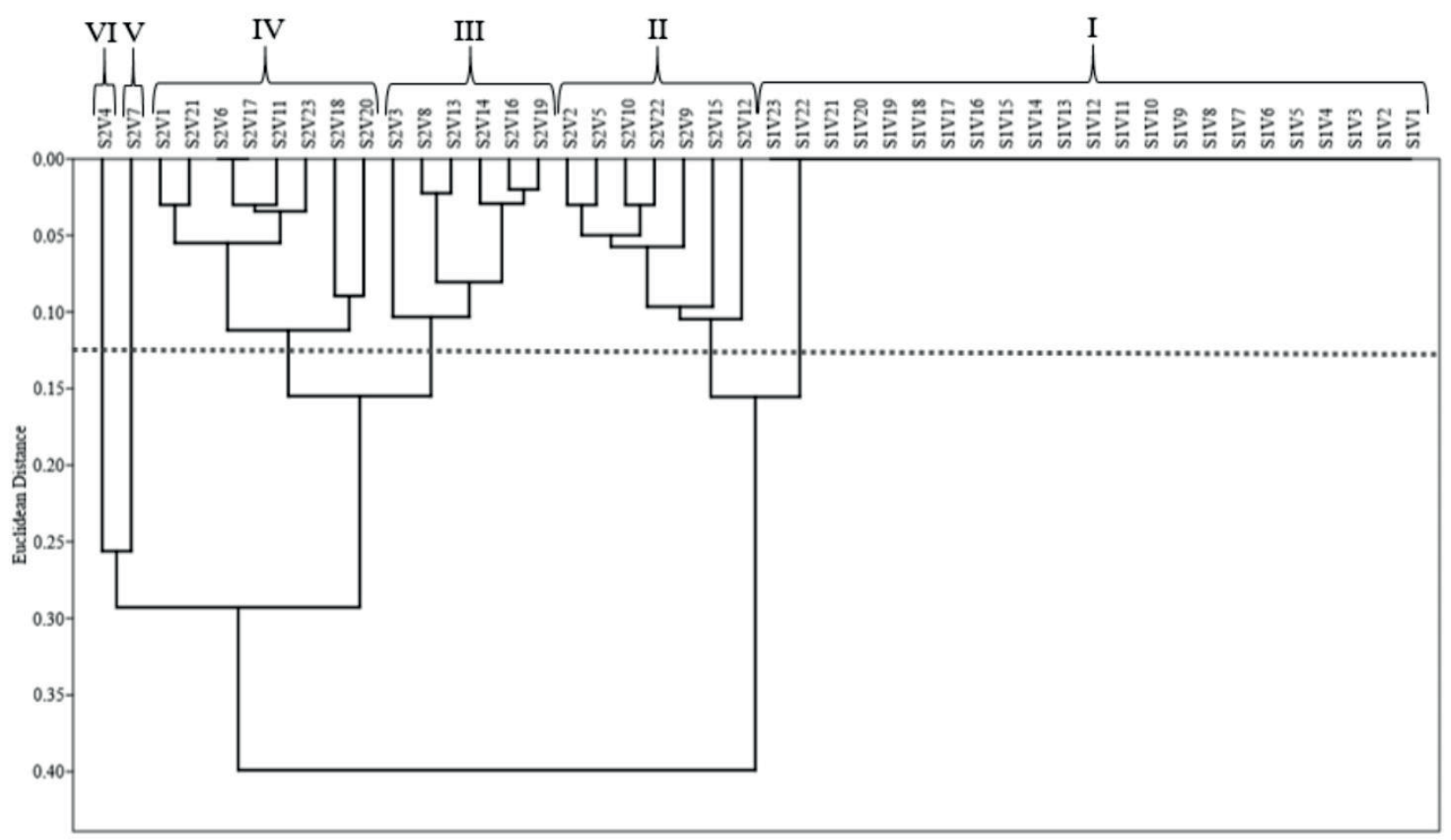

Figure 1. Dissimilarity dendrogram of the groups formed by the combination of salinity levels $(\mathrm{S})$ and cowpea varieties $(\mathrm{V})$

$\mathrm{S} 1$ - Low salinity $\left(0.5 \mathrm{dS} \mathrm{m}^{-1}\right)$; S2 - High salinity $\left(5.5 \mathrm{dS} \mathrm{m}^{-1}\right)$; V1 - Canapu Vermelho; V2 - Boquinha; V3 - Pingo de Ouro; V4 - Sempre Verde; V5 - Ceará; V6 - Baeta; V7 - Manteiga; V8 - Roxão; V9 - Costela de Vaca; V10 - Feijão Branco; V11 - Coruja; V12 - Rabo de Peba Branco; V13 - Sopinha; V14 - Canapu Branco; V15 - Lisão; V16 - Canapu Miúdo; V17 - Sempre Verde Ligeiro; V18 - Vagem Roxa; V19 - Ovo de Peru; V20 - Rabo de Peba Miúdo; V21 - Feijão Azul; V22 - Canário; V23 - Paulistinha.

The dissimilarity dendrogram, based on the Euclidean distance, can be used as an auxiliary tool for the salinity tolerance index, because it is more judicious regarding the groups of higher sensitivity to stress, since the multivariate process takes into account the multiple variables studied.

Identifying materials with potential tolerance to salinity during the germination and initial growth stage is very important, as it can be used as a reference for the establishment of crops in regions with scarce water resources and the presence of salts in irrigation water, such as the semi-arid regions of Northeastern Brazil (Medeiros et al., 2003), where cowpea cultivation is substantial.

\section{Conclusions}

The increase in irrigation water salinity reduced the emergence, vigor, and dry mass accumulation of cowpea varieties.

The varieties Lisão $>$ Costela de Vaca $>$ Canário $>$ Feijão Branco $>$ Ceará $>$ Boquinha, in this order, 
are the most tolerant to salinity in the initial growth stage.

The varieties Rabo de Peba Branco $>$ Ovo de Peru $>$ Canapu Miúdo $>$ Canapu Branco $>$ Sopinha $>$ Roxão $>$ Pingo de Ouro, in this order, are moderately tolerant to salinity in the initial growth stage.

The varieties Vagem Roxa, Rabo de Peba Miúdo, Paulistinha, Coruja, Sempre Verde Ligeiro, Baeta, Feijão Azul, and Canapu Vermelho are moderately sensitive to salinity in the initial growth stage.

The cowpea varieties Sempre Verde and Manteiga, in this order, are the most sensitive to salinity in the initial growth stage.

\section{Reference}

Almeida, W. S., Fernandes, F. R. B., Bertini, C. H. C. M., Pinheiro, M. S., \& Teófilo, E. M. (2012). Emergência e vigor de plântulas de genótipos de feijão-caupi sob estresse salino. Revista Brasileira de Engenharia Agrícola e Ambiental, 16(10), 1047-1054. doi: 10.1590/S1415-43662012001000003.

Aquino, J. P. A., Bezerra, A. A. C., Alcântara, F., Neto, Lima, C. J. G. S., \& Sousa, R. R. (2017). Morphophysiological responses of cowpea genotypes to irrigation water salinity. Revista Caatinga, 30(4), 1001-1008. doi: 10.1590/1983-21252017v30n421rc

Ayers, R. S., \& Westcot, D. W. (1999). A qualidade de água na agricultura (2a ed.). Campina Grande: UFPB.

Barreto, H. B. F., Freitas, R. M. O., Oliveira, L. A. A., Araújo, J. A. M., \& Costa, E. M. (2010). Efeito da irrigação com água salina na germinação de sementes de sabiá (Mimosa caesalpiniifolia Benth). Revista Verde de Agroecologia e Desenvolvimento Sustentável, 5(3), 125-130.

Bernardes, P. M., Mengarda, L. H. G., Lopes, J. C., Nogueira, M. U., \& Rodrigues, L. L. (2015). Qualidade fisiológica de sementes de repolho de alta e baixa viabilidade sob estresse salino. Revista Nucleus, 12(1), 77-86. doi: 10.3738/1982.2278.1105

MAPA. Ministério da Agricultura, Pecuária e Abastecimento (2009). Regras para análise de sementes. Ministério da Agricultura, Pecuária e Abastecimento. Secretaria de Defesa Agropecuária. Brasília: MAPA/ACS.
Chagas, D. L. M., Farias, J. E. C., Souza, R. F., Freitas, S. P., Jr., \& Costa, M. G. S. (2018). Germinação e vigor de sementes crioulas de feijão-caupi. Agrarian Academy, 5(9), 487-498. doi: 10.18677/Agrarian_ Academy_2018a48

Coelho, D. L. M., Agostini, E. A. T., Guaberto, L. M., Machado, N. B., Neto, \& Custódio, C. C. (2010). Estresse hídrico com diferentes osmóticos em sementes de feijão e expressão diferencial de proteínas durante a germinação. Acta Scientiarum Agronomy, 32(3), 491-499. doi: 10.4025/ actasciagron. v32i3.4694

Coelho, J. B. M., Barros, M. F. C., Bezerra, E., Neto, \& Souza, E. R. (2014). Ponto de murcha permanente fisiológico e potencial osmótico de feijão-caupi cultivado em solos salinizados. Revista Brasileira de Engenharia Agrícola e Ambiental, 18(7), 708-713. doi: $10.1590 /$ S1415-43662014000700006

Fageria, N. K., Soares, W. S., Fo ., \& Gheyi, H. R. (2010). Melhoramento genético vegetal e seleção de espécies tolerantes à salinidade. In H. R. Gheyi, N. S. Dias, \& C. F. Lacerda (Eds)., Manejo da salinidade na agricultura: estudos básicos e aplicados (Cap. 13, pp. 205-216). Fortaleza: INCTSal.

Ferreira, D. F. (2014). Sisvar: a Guide for its Bootstrap procedures in multiple comparisons. Ciência $e$ Agrotecnologia, 38(2), 109-112. doi: 10.1590/ S1413-70542014000200001

Gomes, G. R., Almeida, L. H. C., \& Takahashi, L. S. A. (2015). Efeito do estresse hídrico e salino no vigor e germinação de sementes de feijão-vagem (Phaseolus vulgaris L.). Cultura Agronômica, 24(1), 83-92.

Hair, J. F., Black, W. C., Babin, B. J., Anderson, R. E., \& Tatham, R. L. (2009) Análise multivariada de dados. (6a ed.). Porto Alegre: Bookman.

Lopes, K. P., Nascimento, M. G. R., Barbosa, R. C. A., \& Costa, C. C. (2014). Salinidade na qualidade fisiológica em sementes de Brassicas oleracea L. Var. Itálica. Semina: Ciências Agrárias, 35(5), 22512260. doi: 10.5433/1679-0359.2014v35n5p2251

Machado, A. T., Santilli, J., \& Magalhães, R. (2008). A agrobiodiversidade com enfoque agroecológico: implicações conceituais. Brasília: EMBRAPA Informação Tecnológica.

Maguire, J. D. (1962). Speed of germination-aid in selection and evaluation for seedling emergence and vigor. Crop Science, 2(1), 176-177. doi: 10.2135/cro psci1962.0011183X000200020033x 
Medeiros, J. F., Lisboa, R. A., Oliveira, M., Silva, M. J., Jr., \& Alves, L. P. (2003). Caracterização das águas subterrâneas usadas para irrigação na área produtora de melão da Chapada do Apodi. Revista Brasileira de Engenharia Agrícola e Ambiental, 7(3), 469-472. doi: $10.1590 / \mathrm{S} 1415-43662003000300010$

Melo, A. S., Silva, A. R. F., Dutra, A. F., Dutra, W. F., Brito, M. E. B., \& Sá, F. V. S. (2018). Photosynthetic efficiency and production of cowpea cultivars under deficit irrigation. Revista Ambiente e Água, 13(5), e2133. doi: 10.4136/ambi-agua.2133

Oliveira, F. A., Martins, D. C., Oliveira, M. K. T., Souza, M. L., Neta, Ribeiro, M. S. S., \& Silva, R. T. (2014). Desenvolvimento inicial de cultivares de abóboras e morangas submetidas ao estresse salino. RevistaAgro@mbiente On-line,8(2),222-229. doi: 10.18227/1982-8470ragro.v8i2.1540

Oliveira, L. B. (2015). Uso e manejo da água na região semiárida do nordeste do Brasil. Anais da Academia Pernambucana de Ciência Agronômica, 11(1), 5064.

Patel, P. R., Kajalii, S. S., Pateli, V. R., Patel, V. J., \& Khristiii, S. M. (2010). Impact of saline water stress on nutrient uptake and growth of cowpea. Brazilian Journal of Plant Physiology, 22(1), 43-48. doi: 10.1590/S1677-04202010000100005

Porto, F. Q., Fo., Medeiros, J. F., Sousa, E. R., Neto, Gheyi, H. R., \& Matos, J. A. (2006). Viabilidade da irrigação do meloeiro com águas salinas em diferentes fases fenológicas. Ciência Rural, 36(2), 453-459. doi: 10.1590/S0103-84782006000200015
Sá, F. V. S., Ferreira, M., Neto, Lima, Y. B., Paiva, E. P., Gheyi, H. R., \& Dias, N. S. (2017a) Initial development of cowpea plants under salt stress and phosphate fertilization. Revista Ambiente e Água, 12(3), 405-415. doi: 10.4136/ambi-agua.2070

Sá, F. V. S., Nascimento, R., Pereira, M. O., Borges, V. E., Guimaraes, R. F. B., Ramos, J. G.,... Penha, J. L. (2017b). Vigor and tolerance of cowpea (Vigna unguiculata) genotypes under salt stress. Bioscience Journal, 33(6), 1488-1494. doi: 10.14393/BJv33n6a2017-37053

Sá, F. V. S., Paiva, E. P., Torres, S. B., Brito, M. E. B., Nogueira, N. W., Frade, L. J. G., \& Freitas, R. M. O. (2016). Seed germination and vigor of different cowpea cultivars under salt stress. Comunicata Scientiae, 7(4), 450-455. doi: 10.14295/cs.v7i4.154

Santos, P. R., Ruiz, H. A., Neves, J. C. L., Almeida, E. F., Freire, M. B. G. S., \& Freire, F. J. (2009). Germinação, vigor e crescimento de cultivares de feijoeiro em soluções salinas. Revista Brasileira de Engenharia Agrícola e Ambiental, 13(supl.), 882889. doi: 10.1590/S1415-43662009000700010

Souza, L. F., Araújo, M. S., Ferraz, R. L. S., Costa, P. S., Medeiros, A. S., \& Magalhães, I. D. (2019) Sementes crioulas de feijão comum (Phaseolus vulgaris L.) para cultivo agroecológico. Revista Verde de Agroecologia e Desenvolvimento Sustentável, 14(1), 33-40. doi: 10.18378/rvads.v14i1.6482

Syvertsen, J. P., \& Garcia-Sanchez, F. (2014). Multiple abiotic stresses occurring with salinity stress in citrus. Environmental and Experimental Botany, 103(1), 128-137. doi: 10.1016/j.envexpbot.2013. 09.015 